\title{
Proses Keperawatan Sebagai Sistem Dalam
}

\author{
Asuhan Keperawatan \\ Petra Maria Juliana Pasaribu/@petrapasaribu30072001@gmail.com
}

\begin{abstract}
ABSTRAK
Latar Belakang: Persatuan Perawat Nasional Indonesia memberitahukan standar praktik keperawatan professional di Indonesia mengacu pada proses keperawatan yang terdiri atas lima tahap yaitu pengkajian,diagnosis,perencanaan,implementasi,dan evaluasi

Metode : Jenis kajian ini diambil dari beberapa sumber melalui jurnal buku maupun e-book yang isinya berfokus pada proses keperawatan sebagai sistem dalam asuhan keperawatan

Hasil : Hasil yang di dapat dari beberapa sumber yakni proses keperawatan adalah suatu cara sistem dalam memberikan asuhan keperawatan yang dilakukan oleh perawat terhadap pasien bertujuan untuk mengidentifikasi masalah keperawatan untuk mencapai tujuan yang telah ditetapkan.
\end{abstract}

Pembahasan : Proses keperawatan terdiri dari jenis dan komponen sistem serta memiliki teori konsep sistem yang memiliki lima tahap,

Penutup : Sebagai mahasiswa keperawatan kita harus mampu menerapkan setiap komponen sistem agar pasien merasa aman dan nyaman selama berada di rumah sakit.

Kata Kunci : Proses keperawatan,asuhan keperawatan,komponen. 


\section{Latar Belakang}

Sistem perawatan kesehatan berubah dengan cepat serta fleksibel. Perawat zaman sekarang berhadapan dengan perawatan klien yang mengharapkan asuhan keperawatan yang berkualitas dan mengharapkan perawatan professional sebagai penyedia perawatan kesehatan terdidik dengan baik. Proses keperawatan merupakan suatu jawaban untuk pemecahan masalah dalam keperawatan. Karena proses keperawatan merupakan metode ilmiah yang digunakan secara sistematis dan menggunakan konsep dalam mencapai diagnosa masalah kesehatan pasien. keperawatan profesional di Indonesia telah dipaparkan oleh Persatuan Perawat Nasional Indonesia (PPNI) pada tahun 2000.

Standarnya mengacu pada proses keperawatan yang terdiri atas lima tahap, yaitu pengkajian, diagnosis, perencanaan, implementasi, dan evaluasi (dalam Sudono, Setya, dan H, 2017). Pada UU Nomor 38 tahun 2014, pelayanan keperawatan adalah suatu bentuk pelayanan profesional yang merupakan bagian integral dari pelayanan kesehatan yang didasarkan pada ilmu dan kiat keperawatan ditujukan kepada individu, keluarga, kelompok, atau masyarakat, baik sehat maupun sakit. Ilmu keperawatan didasarkan pada suatu teori yang sangat luas. Menurut Lyer dkk (1996) proses keperawatan adalah metode dimana suatu konsep diterapkan dalam praktik keperawatan. Hal ini dapat disebut sebagai suatu pendekatan untuk memecahkan masalah yang memerlukan ilmu, teknik, dan keterampilan interpersonel yang bertujuan untuk memenuhi kebutuhan klien, keluarga, dan masyarakat. Proses keperawatan terdiri atas lima tahap yang berurutan dan saling berhubungan, yaitu pengkajian, diagnosis, perencanaan, implementasi, dan evaluasi. Menurut Zori \& morrison (2009) dalam Sudono, Setya, dan H (2017) asuhan keperawatan merupakan metode ilmiah dalam penyelesaian masalah klien. Kemampuan perawat mengidentifikasi masalah klien dan memilih solusi intervensi yang tepat tidak lepas dari kemampuan perawat beripikir kritis, yaitu kemampuan perawat menggali alasan berdasarkan evidence base dari setiap problem dan solusi yang teridentifikasi. 


\section{Metode}

Metode yang digunakan adalah literature review. Literature review ini menganalisis jurnal, text book, dan ebook yang relevan dan berfokus pada proses keperawatan

\section{Hasil}

Berdasarkan hasil rivew literatur didapatkan hasil bahwa Ketika seorang perawat dapat melakukan pengkajian yang benar kepada pasien, menanyakan kepada pasien secara detail dengan komunikasi yang baik yang membuat pasien menjadi terbuka akan masalahnya dan melakukan Proses keperawatan yang terdiri dari jenis dan komponen system, saat perawat melakukan asuhan keperawatan kepada pasien yang telah dilakukan pengkajian tersebut akan lebih mudah dikarenakan perawat sudah mengetahui masalah apa yang dimiliki oleh pasien dan bagaimana cara pemberian asuhan keperawatan pada pasien tersebut. Pengkajian keperawatan dan asuhan keperawatan memiliki hubungan erat yang baik bagi si perawatnya. Proses keperawatan adalah suatu cara atau metode yang sistematis dalam memberikan asuhan sebagai metode dalam memberikan asuhan keperawatan. Jurnal-jurnal yang digunakan adalah jurnal yang diterbitkan 10 tahun terakhir

keperawatan yang dilakukan oleh perawat dan bekerjasama dengan pasien (individu, keluarga, masyarakat) yang bertujuan untuk mengidentifikasi masalah keperawatan dengan melakukan pengkajian, menentukan, diagnosa, merencanakan tindakan yang akan dilakukan, melaksanakan tindakan serta mengevaluasi hasil asuhan keperawatan yang telah diberikan dengan berfokus pada pasien, berorientasi pada tujuan yang telah ditetapkan bersama (Budiono, 2016). Proses keperawatan merupakan alat bagi perawat untuk melaksanakan asuhan keperawatan terhadap pasien yang memilki arti penting bagi kedua belah pihak. Seorang perawat dapat menggunakan proses keperawatan sebagai pedoman dalam memecahkan masalah pasien, menunjukkan profesi yang memiliki profesionalitas yang tinggi, serta dapat memberikan kebebasan kepada pasien untuk mendapatkan pelayanan yang cukup 
sesuai dengan kebutuhan (Alimul, 2009).

Hasil ini meliputi bagaimana proses

keperawatan sebagai sistem dalam asuhan

keperawatan.

\section{Pembahasan}

Undang-undang No. 38 Tahun 2014, yang dimaksud dengan asuhan keperawatan adalah rangkaian interaksi antara perawat dengan klien dan lingkungannya untuk mencapai tujuan pemenuhan kebutuhan dan kemandirian klien dalam merawat dirinya dan proses keperawatan menjadi alat bagi perawat untuk melaksanakan pemberian asuhan keperawatan yang dilakukan pada pasien dan memiliki arti penting bagi kedua belah pihak yaitu perawat dan klien.

Sebagai seorang perawat proses keperawatan dapat digunakan sebagai pedoman dalam pemecahan masalah klien, dapat menunjukkan profesi yang memiliki profesionalitas yang tinggi, serta dapat memberikan kebebasan pada klien untuk mendapatkan pelayanan yang cukup sesuai dengan Menurut Mahyar Suara.dkk pada tahun 2010 proses keperawatan adalah suatu metode yang sistematis dan terorganisasi dalam melakukan pemberian asuhan keperawatan,yang difokuskan pada reaksi dan responsuntuk individu terhadap suatu kelompok atau perorangan terhadap gangguan kesehatan yang dialami, baik actual maupun potensial. Proses keperawatan juga dapat diartikan sebagai pendekatan yang digunakan perawat dalam memberikan asuhan keperawatan sehingga kebutuhan dasar klien dapat terpenuhi,dan perlu dilakukan pengkajian keperawatan terlebih dahulu sebelum melakukan asuhan keperawatan supaya asuhan keperawatan yang diberikan oleh perawat kepada pasien dapat dilakukan lebih optimal dan baik.Tujuan Asuhan Keperawatan ialah Membantu klien untuk menjadi lebih mandiri,Menganjurkan klien, keluarga dan masyarakat untuk berpartisipasi dalam bidang kesehatan, Membantuk klien mengembangkan potensi dalam memelihara derajat kesehatan secara optimal sehingga diharapkan tidak ketergantungan pada orang lain dalam memelihara kesehatannya sendiri, Membantu klien untuk mencapai derajat kesehatan yang optimal Dengan adanya asuhan keperawatan dapat meningkatkan derajat kesehatan klien sehingga klien dapat menjadi lebih mandiri dalam keadaan sakit maupun dalam keadaan sehat.Antara pengkajian keperawatan dan proses keperawatan memiliki hubungan, semakin baik 
seorang perawat melakukan pengkajian maka semakin baik juga perawat dalam memberikan asuhan keperawatan kepeda pasien perawat adalah seseorang yang telah Lulus pendidikan perawat, baik di dalam maupun di luar negeri sesuai dengan ketentuan peraturan perundang-undangan yangberlaku (Kepmenkes RI No. 1239, 2001) Perawat dalam memberikan pelayanan kepada klien ataupun dalam melakukan praktek keperawatan diharapkan memiliki pemahaman yang sama terhadap hakikat keperawatan sebagai profesi, praktek keperawatan profesional serta peran dan fungsi perawat profesional. Dalam hal ini perawat dituntut melaksanakan peran dan fungsinya sesuai dengan harapan profesi keperawatan dan masyarakat sebagai pengguna jasa pelayanan keperawatan. Rumah Sakit adalah institusi pelayanan kesehatan bagi masyarakat dengan karateristik tersendiri yang dipengaruhi oleh perkembangan ilmu pengetahuan kesehatan, kemajuan teknologi, dan kehidupan sosial ekonomi masyarakat yang harus tetap meningkatkan pelayanan yang lebih bermutu dan terjangkau oleh masyarakat agar terwujudnya derajat kesehatan yang tinggi, seperti yang tertera pada Undang-Undang Kesehatan Nomor 36 Tahun 2009 dan Undang-Undang Rumah
Sakit Nomor 44 Tahun 2009 bahwa rumah sakit wajib melaksanakan pelayanan kesehatan yang aman,bermutu, dan efektif, dengan mengutamakan kepentingan pasien. Rumah sakit wajib memenuhi hak pasien memperoleh keamanan dan keselamatan selama dalam perawatandi rumah sakit. (Permenkes RI Nomor 1961/Menkes/2011). Tahap evaluasi merupakan tahap terakhir dari proses keperawatan yang berupa perbandingan sistematis dan terencana dari hasil-hasil yang diamati dengan tujuan dan kriteria hasil yang dibuat pada tahap perencanaan. Evaluasi dilakukan dengan cara berkesinambungan Proses keperawatan merupakan lima tahap yang konsisten sesuai dengan perkembangan profesi keperawatan. Tahapnya pertama kali Pada tahun 1967 Yura dan Walsh memaparkan menjadi empat tahap, yaitu pengkajian,perencanaan, implementasi, dan evaluasi. Pada tahun yang sama, edisi pertama proses keperawatan dipubikasikan dalam empat tahap yang meliputi pengkakjian, perencanaan, implementasi, dan evaluasi.Pertengahan tahun 1970-an, Bloch (1974), Roy (1975), Mundunger dan Jauron (1975) serta Aspinal (1976) menambahkan tahap diagnosis pada proses keperawatan sehingga menjadi lima tahap yaitu pengkajian, diagnosis, perencanaan, implementasi, dan evaluasi. 
Dengan berkembangnya waktu, proses keperawatan telah dianggap sebagai suatu dasar hukum dalam praktik keperawatan. Pada tahun 1973, American Nursing association (ANA) menggunakan proses keperawatan sebagai pedoman dalam pengembangan standar praktik keperawatan dan digunakan sebagai suatu kerangka konsep kurikulum pendidikan keperawatan.

Di Indonesia, definisi dan tahap-tahap proses keperawatan telah digunakan sebagai dasar pengembangan definisi dan standar legal praktik keperawatan dan juga sebagai kriteria dalam program sertifikasi. Kurikulum pendidikan keperawatan pada setiap jenjang pendidikan (D3, S1, S2, maupun S3) saat ini telah menggunakan proses keperawatan sebagai kerangka kerjanya (Nursalam, 2008). Pengertian Proses Keperawatan Proses keperawatan adalah sarana atau alat yang digunakan oleh seorang perawat dalam bekerja dan tata cara pelaksanaanya tidak boleh dipisah pisah antara tahap pertama, kedua, ketiga dan seterusnya. Tahap pertama pengkajian, tahap kedua menegakkan diagnosa keperawatan, tahap ketiga menyusun rencana keperawatan yang mengarah kepada penanganan diagnose keperawatan, tahap keempat diimplementasikan dan tahap kelima atau tahap terakhir adalah evaluasi. Orientasi dari pelayanan asuhan keperawatan adalah pada pencapaian tujuan asuhan keperawatan. Asuhan keperawatan yang telah ditetapkan dalam perencanaan keperawatan telah tercapai (Budiono, 2016). Tujuan penerapan proses keperawatan bagi klien adalah Mempertahankan kesehatan klien,Mencegah sakit yang lebih parah/ penyebaran penyakit/komplikasi akibat penyakit, Membantu pemulihan kondisi klien setelah sakit, Mengembalikan fungsi maksimal tubuh,Membantu klien termial untuk meninggal dengan tenang. Tujuan penerapan proses keperawatan dalam praktik keperawatan; Mempraktikan metode pemecahan masalah dalam praktik keperawatan, Meggunakn standar praktik keperawatan, Memperoleh metode yang baku,rasional, dan sistematis,Memperoleh hasil asuhan keperawatan dengan efektivitas yang tinggi.(Asmadi, 2008) Manfaat proses keperawatan bagi perawat ialah, Akan mempunyai rasa percaya diri, karena semua perencanaan disusun dengan baik berdasarkan kepada diagnosa keperawatan yang ditunjang oleh data-data yang tepat dan akurat, Kepuasan kerja, karena memberikan peningkatan kualitas asuhan keperawatan sehingga mempercepat proses kesembuhan pasien, Pengembangan profesionalisme keperawatan pada umumnya. Manfaat 
proses keperawatan bagi klien adalah Klien akan ikut berpartisipasi dalam menentukan perencanaan keperawatan dan akan meningkatkan kerjasama klien dalam pelaksanaan tindakan keperawatan, Proses keperawatan menjamin klien akan mendapatkan asuhan keperawatan yang berkesinambungan. Mencegah terjadinya duplikasi tindakan dan kekurangan tindakan. Klien akan mendapatkan kualitas pelayanan asuhan keperawatan yang prima. Manfaat proses keperawatan bagi rumah sakit atau puskesmas adalah Kepuasan klien Dengan sendirinya klien akan menceritakan kepuasannya kepada orang lain sehingga orang lain berkeinginan untuk mendapatkan kepuasan tersebut, Meningkatkan jumlah klien.Menurut budiono (2016) ada beberapa sifat proses keperawatan :Terbuka dan fleksibel Proses keperawatan menganut sistem terbuka. Jika sewaktu-waktu terjadi perubahan respon klien maka akan memberikan perubahan terhadap diagnosa, rencana dan tindakan yang akan diberikan. Fleksibel karena semua rencana yang telah disusun tidak serta merta harus dilaksanakan seluruhnya,tetapi harus melihat perubahan dan perkembangan kondisi,Dilakukan melalui pendekatan individual.Ada banayak hal yang bersifat individual dan merupakan privasi klien. Sehingga tidak kepda semua perawat diberikan kepercayaan oleh klien, atau tidak semua data (yang berhubungan dengan masalah keperawatan) akan disampaikan oleh klien. Pada situasi ini maka dibutuhkan suatu pendekatan yang individual kepada klien,Penanganan masalah terencana Setelah masalah keperawatan ditemukan, maka akan disusun perencanaan yang berlandasarkan kepada ilmu keperawatan yang kokoh, Mempunyai arah dan tujuan Perencanaan yang disusun mempunyai arah dan tujuan yang akan dicapai dalam batasan waktu tertentu, Merupakan siklus yang saling berhubungan Evaluasi merupakan tahapan terakhir dalam proses keperawatan. Evaluasi dapat berupa perbandingan yang sistematis dan terencana dari berbagai hasil yang diamati dengan tujuan dan kriteria hasil yang dibuat pada tahap perencanaan. Evaluasi dilakukan secara berkesinambungan dengan melibatkan pasien dengan tenaga kesehatan lainnya. Hasil dari evaluasi menentukan nasib pasien untuk kedepannya. Apabila hasil menunjukkan tercapainya tujuan dan kriteria hasil, maka pasien akan keluar dari proses perawatan dan diperkenankan untuk pulang. Namun sebaliknya, apabila kriteria hasil dan tujuannya belum tercapai maka pasien masuk kedalam siklus proses keperawatan mulai dari pengkajian ulang. 


\section{Penutup}

Berdasarkan jurnal diatas Sebagai

mahasiswa keperawatan kita harus mampu menerapkan setiap komponen sistem agar pasien merasa aman dan nyaman selama berada di rumah sakit. Sebagai wujud dari penerapan asuhan keperawatan sebgai bagian dari proses sebagai system, Karena proses keperawatan merupakan salah satu system dalam memecahkan masalah keperawatan yang bersifat fleksibel dalam memenuhi kebutuhan pasien dengan memberikan asuhan keperawatan dengan dilakukan secara sistematis sehingga meningkatkan kualitas pelayanan keperawatan.

\section{Daftar Pustaka}

Aini,Nur.(2018). Teori Model Keperawatan Beserta Aplikasinya Dalam Keperawatan Malang: Penebit Universitas

Muhammadiyah Malang.

Allen, C. V. (1998). Memahami Proses

Keperawatan dengan Pendekatan Latihan. Jakarta: EGC.

Astari,A.,Houghty.G.S.,br

Sibuea,R.O.(2015).Sosialisasi Profesi dan
Sikap caring pada mahasiswa difakultas keperawatan.1(1).66-74.

Asmadi. (2008). Konsep Dasar

Keperawatan. Jakarta: EGC.

Arifah Mutia Saroh. Proses Keperawatan

Sebagai Metode Dalam Memberikan

Asuhan Keperawatan. Osf.io

Budiono. (2016). Konsep Dasar

Keperawatan . Jakarta: Kementerian

Kesehatan Republik Indonesia.

Bumulo, M. I., Bidjuni, H., \& Bawotong, J. (2017, Agustus). Pengaruh Manajemen Model Asuhan Keperawatan Profesional Tim terhadap Kualitas Pelayanan Keperawatan di Bangsal Pria RSUD Datoe Binangkang Kabupaten Bolang Mongondow. e-Jurnal Keperawatan (e-Kp), 5,16

Carthon, J. M. B., Hatfield, L., Plover, C., Dierkes, A., Davis, L., Hedgeland, T., ... \& Del Guidice, M. (2019). Association of nurse engagement and nurse staffing on patient safety. Journal of nursing care quality,34(1), 40-46

DS, B. S., A, D. s., \& H, R. A. (2017,April). Gambaran Kemampuan Brpikir Kritis Perawat Primer dalam Pelaksanaan Asuhan Keperawatan Di Rumah sakit Islam 
Surakarta Vol 10 No 1. Jurnal Ilmu

Keperawatan Indonesia.

Hidayah, N. (2014). Manajemen Model Asuhan Keperawatan Profesional (MAKP) Tim Dalam Peningkatan Kepuasan Pasien di Rumah Sakit Volume VII No. 2. Jurnal Kesehatan.

Husna, A. (2019). Tingkat Berpikir Kritis Dalam Keperawatan. Osf.io

Kartika, I. R., Hariyati, R. S., \& Nelwati. (2018, Maret). Kompetensi Perawat dan Kepuasan Pasien Terhadap Pelayanan Keperawatan di Rawat Jalan Volume 14 No. 2. Jurnal Keperawatan

Khamida, \& Mastiah. (2015, Agustus).

Kinerja Perawat dalam Memberikan Asuhan Keperawatan Berpengaruh trehadap Kepuasan Pasien Rawat Inap Vol 8 No. 2. Jurnal Ilmiah Kesehatan, 154-161.

Komarudin.(2018).Pendidikan Keperawatan Berkelanjutan dalam Pencapain

Sustaiability Profesionalisme

Keperawatan.3(2).139151.

Kodim, Yulianingsih. (2015). Konsep Dasar Keperawatan. jakarta: TIM.

Kusnanto.(2004).Pengantar Profesi dan Praktik Keperawatan Profesional.Jakarta:

Penerbit Buku Kedokteran EGC

Marwa, A. U. (2019). Hubungan

Berpikir Kritis Dalam Keperawatan

Terhadap Pasien

Prasekolah.INA-Rxiv.September,27.

Nursalam. (2008). Proses dan Dokumentasi

Keperawatan. Jakarta: Salemba Medika.
Potter,P.A., \&Perry,A.G.(2005).Buku Ajar Fundamental Keperawatan konsep Proses dan Praktek(edisi 4).Jakarta: Penerbit Buku Kedokteran EGC

Sari,D.A., Wijaya,D.,Purwandari,R.(2017).H ubungan PersepsiMahasiswa tentang Profesi Keperawatan dengan Motivasi Melanjutkan Pendidikan Profesi Ners di PSIK UniversitasJember.5(3).505-512

Saudin,D.,Kristianto,H.(2016).Rancangan Media Pembelejaran dengan Konsep Dasar Keperawatan Kegawat daruratan.4(02).29-35

Simamora, R. H. (2019) Menjadi Perawat yang: CIH'HUY. Surakarta: Kekata Publisher. Suprajitno. (2004). Asuhan Keperawatan Keluarga : Aplikasi dalam Praktik. Jakarta: EGC.

Simamora. R. H. (2008) The correlation of ward chief's giving direction and command and the performance of on-duty nurses at Jember dr. Subandi general hospital inpatient wards. jurnal Administrasi dan Kebijakan Kesehatan,

(https://fkm.unair.ac.id/jurnal-administr)

Supratti, \& Ashriady. (2016, juli). Pendokumentasian Standar Asuhan Keperawatan di Rumah Sakit Umum Daerah Mamuju, Indonesia. Jurnal Kesehatan Manarang, 2, 44-51.

Yanti, R. I., \& Warsito, B. E. (2013, November). Hubungan Karakteristik Perawat, Motivasi, dan Supervisi dengan Kualiatas Dokumentasi Proses Asuhan Keperawatan. Jurnal Managemen Keperawatan, 2, 107-114. 
